\title{
Catechins- a natural blessing in Breast cancer treatment
}

\author{
Wajeeha Iffat ${ }^{1}$ and Sohail Hussain ${ }^{2 *}$ \\ ${ }^{1}$ Department of Biotechnology, Jamia Hamdard, India \\ ${ }^{2}$ Department of Pharmacology and Toxicology, Jazan University, Kingdom of Saudi Arabia
}

*Corresponding author: Sohail Hussain, Department of Pharmacology and Toxicology, Jazan University, Kingdom of Saudi Arabia.

To Cite This Article: Sohail Hussain, Catechins- a natural blessing in Breast cancer treatment. Am J Biomed Sci \& Res. 2019 - 6(5). AJBSR. MS.ID.001066. DOI: 10.34297/AJBSR.2019.06.001066.

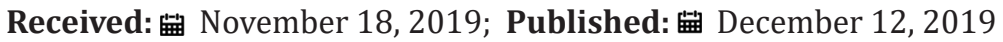

\section{Introduction}

Breast malignant growth is a typical disease in female. There were an expected 1.7 million new cases $(25 \%$ of all tumors in female) and 0.5 million malignant growth passings (15\% of all disease deaths in female) in 2012 [1]. In spite of the fact that there have been incredible advances in the treatment of breast disease, mortality from breast malignant growth is still high and it is the subsequent driving reason for disease related passing among female in the United States [2]. A few regenerative and way of life factors are likewise connected with the advancement of breast malignant growth. Among the regenerative components are long menstrual history, nulliparity, expanded utilization of oral contraceptives, and bringing forth a kid at later age [3]. Way of life factors including less physical movement, utilization of unhealthy eating regimens, cigarette smoking and liquor utilization are emphatically connected with expanded danger of breast disease advancement [4]. By 2030, WHO International expected that $25 \%$ of individuals around the globe will have at any rate one malignancy type. Over $60 \%$ of new cases are normal in low-and center salary regions [5].

The present review will feature the ongoing advances in the impacts of tea and its catechins on breast malignant growth, including epidemiological, in vivo, and in vitro investigations. Tea is one of the most well-known drinks devoured everywhere throughout the world. Tea leaves are wealthy in catechins, a gathering of polyphenols that supply tea with numerous medical advantages. (-)- Epigallocatechingallate (EGCG), (-)- epicatechingallate (ECG), $(-)$ - epigallocatechin (EGC) and (-)- epicatechin (EC) are the significant catechins in crisp tea leaf [6]. Green tea polyphenols (GTP) are viewed as a potential contender for further advancement as a chemoprotective factor for the essential anticipation of agerelated eye disease [7]. There have been epidemiological and in vitro investigations in regard to the relationship of tea utilization with depression among breast malignancy survivors [8]. Drinking tea or green tea was not related with by and large breast malignancy hazard [9]. Be that as it may, the impacts of tea and its catechins on the avoidance of breast malignant growth are as yet uncertain and dubious [10].

\section{Epidemiological Evidence}

As ahead of schedule as 1997, an epidemiological examination completed in Japan demonstrated that drinking green tea had a possibly preventive impact on breast malignant growth, particularly among female who drank in excess of 10 cups of green tea every day [11]. Numerous partner studies or case-control examines on the relationship between tea utilization and breast malignant growth hazard have been completed from that point forward. Partner thinks about in China and the USA demonstrated that ongoing drinking of green tea was pitifully connected with a diminished danger of breast malignant growth [12]. The relationship between tea utilization and diminished danger of breast disease was likewise affirmed by populace-based case-control examines completed in China [13], the USA [14] and Singapore [15].

\section{Mechanism of Tea Catechins in Suppressing Breast Cancer}

Reactive oxygen species can possibly prompt harm of practically a wide range of natural particles including DNA, lipids, proteins, and starches [16]. Oxidative stress results after the extreme generation of responsive oxygen species that abrogates the cancer prevention agent capacity of the objective cells [17]. Results are DNA harm, creation of mutated tumor-silencer qualities, and actuating cell demise [18]. These neurotic occasions are engaged with cardiovascular, neurodegenerative, and cancer-causing forms [19]. Improved cancer prevention agent protection brings 
about decreased pervasiveness of female related with oxidative stress [20]. They have been seen as very effective in the aversion of specific infections for quite a long time particularly malignancy [21]. The substance, in vitro and organic measures, showed green tea polyphenols as solid cancer prevention agents in their action against iodophenol-inferred phenoxyl radicals, superoxide anion radicals, and lipid peroxidation in rodent liver microsomes [22]. EGCG is a significant forager of reactive oxygen species and has solid cancer prevention agent movement [23].

A few trial thinks about investigated that green tea has anticarcinogenic impacts against breast disease. EGCG are viable in stifling the multiplication of MDA-MB-231, a profoundly obtrusive estrogen receptor-negative breast malignant growth cell line as appeared by development restraint and apoptosis induction [24]. Treatment of human MCF-7 cells with 50 microM EGCG can bring some positive changes as apoptosis, mitochondrial layer potential changes, and activation of c-Jun N-terminal kinase (JNK), caspase- 9 and caspase-3 [25]. In another examination EGCG stifled cell practicality and initiated apoptosis by the downregulation of telomerase and repressed angiogenesis by decreasing the expression of vascular endothelial development factor (VEGF) in a portion subordinate [26]. The rate of apoptosis and action of caspase- 3 initiated by EGCG was time, and portion, subordinate. Most of in vivo thinks about exploring the helpful impacts of green tea constituents in breast malignancy chemoprevention have concentrated on green tea polyphenol blends instead of decontaminated singular catechins.

Investigations of synthetic actuated mammary carcinogenesis led in rodents have shown a defensive impact of green tea mixes on tumor weight and endurance, however it is as yet hazy whether this security is more prominent at the pre-or post-commencement arrange [27]. Different thinks about utilizing either green tea removes or sanitized EGCG have additionally been led utilizing breast disease cell xenografts in mice. Sartippour et al. [28] utilized SCID mice immunized with MDA-MB-231 breast malignancy cells to delineate that tumor development, tumor weight and endothelial vessel thickness following green tea utilization diminished contrasted with control [29]. Baliga et al. [30] likewise exhibited postponed tumor development beginning, pace of tumor development, tumor volume and metastasis following a green tea polyphenol blend in the drinking water of BALB/c mice vaccinated with 4T1 mouse mammary carcinoma cells. These discoveries recommend that EGCG may be valuable in the treatment and additionally counteractive action of breast disease by inciting apoptosis.

In vitro, epigallocatechin, another significant catechin in green tea, likewise has solid impacts in initiating apoptosis and hindering development of breast malignant growth cells [31]. Epidemiologic contemplates have proposed that the customary utilization of tea, especially green tea, reasonably diminishes the danger of malignant growth. These outcomes were altogether upheld with meta-examination did by Sun et al. [32] and Zhang et al. [10] gave definitive thoughts in regard to counteractive action and taking out the danger of breast malignancy.

\section{Conclusion}

EGCG initiates apoptosis in breast malignancy cells in vitro. The cytotoxic impact of this netraceutical isn't affected by the hormone receptor status of breast malignant growth cell lines. Moreover, a pervasive instrument might be liable for the EGCG-intervened acceptance of apoptosis. Upon treatment with EGCG in breast malignant growth cells exhibited cell cycle capture in G1 stage. This is probably going to be the consequence of a lessening in the auto-phosphorylative limit of EGFR and an ensuing decrease in the movement of intracellular flagging falls, which are actuated by EGFR. These progressions may prompt modifications in the declaration of proteins administering the phone cycle. The essential objective of malignant growth chemoprevention contemplates with dietary constituents is to distinguish dynamic fixings and to clarify their basic instruments for structuring a superior routine or procedure for intercession preliminaries. Of the most widely explored and well-characterized dietary chemo preventives.

\section{References}

1. Stewart BW, Wild CP (2014) World Cancer Report, World Health Organization, Chapters 1.1 and 5, French.

2. Kushi LH, Doyle C, McCullough M, Rock CL, Demark-Wahnefried W, et al. (2012) American cancer society guidelines on nutrition and physical activity for cancer prevention: Reducing the risk of cancer with healthy food choices and physical activity. CA Cancer J. Clin. 62(1): 30-67.

3. Hulka BS, Moorman PG (2001) Breast cancer: hormones and other risk factors. Maturitas 38:103-113.

4. Donohoe CL, Doyle SL, Reynolds JV (2011) Visceral adiposity, insulin resistance and cancer risk. Diabetol Metab Syndr 3: 12.

5. Stefan C (2018) Will a global fund for cancer be the answer? Nat Rev Clin Oncol. 15(4): 195-196.

6. Liang YR, Ye Q Jin J, Liang H, Lu JL, et al. (2008) Chemical and instrumental assessment of green tea sensory preference. Int. Food Prop 11: 258-272.

7. Xu JY, Wu LY, Zheng XQ, Lu JL, Wu MY, et al. (2010) Green tea polyphenols attenuating ultraviolet $\mathrm{b}$-induced damage to human retinal pigment epithelial cells in vitro. Invest. Ophthalmol Vis Sci 51(12): 6665-6670.

8. Chen X, Lu W, Zheng Y, Gu K, Chen Z, et al. (2010) Exercise, tea consumption, and depression among breast cancer survivors J Clin Oncol 28(6): 991-998.

9. Li M, Tse LA, Chan WC, Kwok CH, Leung SL, et al. (2016) Evaluation of breast cancer risk associated with tea consumption by menopausal and estrogen receptor status among Chinese women in Hong Kong. Cancer Epidemiol. 40: 73-78.

10.Zhang M, Holman CDAJ, Huang JP, Xie X (2007) Green tea and the prevention of breast cancer: A case-control study in Southeast China. Carcinogenesis 28(5): 1074-1078

11. Imai K, Suga K, Nakachi K (1997) Cancer-Preventive effects of drinking green tea among a Japanese population. Prev Med 26(6): 769-775. 
12. Shrubsole MJ, Lu W, Chen Z, Shu XO, Zheng Y, et al. (2009) Drinking Green Tea Modestly Reduces Breast Cancer Risk. J Nutr 139(2): 310-316.

13. Zhang M, Huang J, Xie X, Holman CDAJ (2009) Dietary intakes of mushrooms and green tea combine to reduce the risk of breast cancer in Chinese women. Int. J. Cancer 124(6): 1404-1408.

14. Kumar N, Titus-Ernstoff L, Newcomb PA, Trentham-Dietz A, Anic G, et al. (2009) Tea consumption and risk of breast cancer. Cancer Epidemiol. Biomark 18(1): 341-345.

15. Inoue M, Robien K, Wang R, Berg DJVD, Koh WP, et al. (2008) Green tea intake, MTHFR/TYMS genotype and breast cancer risk: The Singapore Chinese Health Study. Carcinogenesis 29(10): 1967-1972.

16. Valko M, Leibfritz D, Moncol J, Cronin MT, Mazur M, et al. (2007) Free radicals and antioxidants in normal physiological functions and human disease. Int J Biochem Cell Biol. 39(1): 44-84.

17. Vina J, Borras C, Gomez-Cabrera MC, Orr WC (2006) Part of the series: from dietary antioxidants to regulators in cellular signalling and gene expression. Role of reactive oxygen species and (phyto) oestrogens in the modulation of adaptive response to stress. Free Radic Res 40(8): 111-119.

18. Farah IO (2005) Assessment of Cellular Responses to Oxidative Stress using MCF-7 Breast Cancer Cells, Black Seed (N. Sativa L.) Extracts and H202. Int J Environ Res Public Health 2: 411-419.

19. Ferrari CK (2004) Functional foods, herbs and nutraceuticals: towards biochemical mechanisms of healthy aging. Biogerontol. 5(5): 275-289.

20. Ji LL, Peterson DM (2004) Aging, exercise, and phytochemicals promises and pitfalls. Ann NY Acad Sci 1019: 453-461.

21. Berger MM (2005) Can oxidative damage be treated nutritionally? Clin Nutr 24(2): 172-83.

22. Katiyar SK, Mukhtar H (1997) Tea antioxidants in cancer chemoprevention J Cell Biochem Suppl 27: 59-67.

23. Norwood AA, Tan M, May M, Tucci M, Benghuzzi H (2006) Comparison of potential chemotherapeutic agents, 5 fluoruracil, green tea, and thymoquinone on colon cancer cells. Biomed Sci Instrum. 42: 350-356.
24. Thangapazham RL, Singh AK, Sharma A, Warren J, Gaddipati JP (2006) Green tea polyphenols and its constituent epigallocatechin gallate inhibits proliferation of human breast cancer cells in vitro and in vivo. Cancer Lett 245(1-2): 232-241.

25. Hsuuw YD, Chan WH (2007) Epigallocatechin gallate dosedependently induces apoptosis or necrosis in human MCF-7 cells. Ann. NY Acad Sci 1095: 428-440.

26. Mittal A, Pate M, Wylie R, Tollefsbol T, Katiyar S (2004) EGCG downregulates telomerase in human breast carcinoma MCF-7 cells, leading to suppression of cell viability and induction of apoptosis. Int J Oncol 24(3): 703-710.

27. Kavanagh KT, Hafer LJ, Kim DW, Mann KK, Sherr DH, et al. (2001) Green tea extracts decrease carcinogen-induced mammary tumour burden in rats and rate of breast cancer cell proliferation in culture. Journal of Cellular Biochemistry 82(3): 387-398.

28. Sartippour MR, Heber D, Ma J, Lu Q, Go VL, et al. (2001) Green tea and its catechins inhibit breast cancer xenografts. Nutrition and Cancer 40(2): 149-156.

29. Baliga MS, Meleth S, Katiyar SK (2005) Growth inhibitory and antimetastatic effect of green tea polyphenols on metastasis-specific mouse mammary 4T1 cells in vitro and in vivo. Clinical Cancer Research 11(5): 1918-1927.

30. Stewart AJ, Mullen W, Crozier A (2005) On-line high-performance liquid chromatography analysis of the antioxidant activity of phenolic compounds in green and black tea. Mol Nutr Food Res 49(1): 52-60.

31. Weisburger jH, Rivenson A, Reinhardt J, Aliaga C, Braley J, et al. (1998) Effect of black tea on azoxymethane-induced colon cancer. Carcinogenesis 19(1): 229-232.

32. Sun CL, Yuan JM, Koh WP, Yu MC (2006) Green tea, black tea and breast cancer risk: a meta-analysis of epidemiological studies. Carcinogenesis. 27(7): 1310-1315. 